$\$=19$

\title{
A revision on Urena lobata $\mathbf{L}$.
}

\author{
Muhammad Torequl Islam ${ }^{1,2}$, Mohammad Ashab Uddin ${ }^{1}$ \\ ${ }^{1}$ Department of Pharmacy, Southern University Bangladesh, Mehedibag (Chittagong)-4000, Bangladesh \\ ${ }^{2}$ Postgraduate Program in Pharmaceutical Sciences, Federal University of Piauí, Teresina (Piauí)- 64.049-550, Brazil \\ *Corresponding author E-mail: rbiotufpi.br@gmail.com
}

\begin{abstract}
The medicinal plant, Urena lobata L. (Malvaceae) is commonly known as aramina fibre, caesarweed or congo jute is widely distributed in Bangladesh. The ethnopharmacological usages of the parts of this plant are antique for the treatment of various diseases. In the recent years, a number of scientific evidences have been seen on its isolated phytochemicals and biological activities. This review offers a current scenario of the $U$. lobata, emphasized on the phyto-pharmacological findings. A search was made in the electronic databases such as PubMed, Science Direct and Google scholar for the published articles till January 31, 2017. To date, several important flavonoids, glycosides and terpenoids have been isolated from this plant. $U$. lobata possesses promising biological activities, including antioxidant, inflammatory, antimicrobial, anticancer, anti-diarrheal, anti-diabetic, anti-hyperlipidemic, neuropharmacological etc. U. lobata may be one of the good sources of therapeutic phytochemicals.
\end{abstract}

Keywords: Ethnopharmacological Uses; Phytoconstituents; Biological Activities.

\section{Introduction}

Medicinal plants and their derived products are one of the potential sources of modern medicines. The use of medicinal plants or their parts is long standing and increasing day by day (Islam et al. 2016).

Urena lobata (Malvaceae), a sub-shrub, is traditionally used in many countries, including Bangladesh, India and China to treat various ailments (Sajem \& Gosai 2006; Gao et al. 2015; Medicinal Plants of Bangladesh 2017). The scientific reports also suggest that $U$. lobata may be a good source of promising phytotherapeutic chemical moieties (Babu et al. 2016).

This review provides a profile on the botanical, phytochemical, and biological and other activities of $U$. lobata.

\section{Revision findings}

\subsection{Methods}

\subsubsection{Stratagem}

A search was made in the PuBMed, Science Direct and Google scholar databases with the keyword 'Urena lobata', which was then paired with 'morphology', 'traditional/ethnopharmacological uses', 'phytochemicals' and 'pharmacological activities'. The obtained evidences were included and excluded as follows: Inclusion criteria:

a) In vitro, ex vivo and in vivo studies on $U$. lobata.

b) Phytochemical and/or pharmacological reports on U. lobata.

c) Reports on extract(s) or isolated compound(s) and their activities.

\subsubsection{Exclusion criteria}

a) Data not related to the focusing study.

b) Reports on other species of Urena genus.

c) Data duplication.

\subsubsection{Findings}

To date, a total 151 articles were found in which Science Direct, Google scholar and PubMed belonged to 126, 14 and 11 respectively. After exclusion, 27 were included in this study.

\subsubsection{Ethnic identification}

The Bengali/vernacular name of $U$. lobata (plant taxonomy: Box 1) is banokra, atlera, nageji, jangli ghagra; belaz-gota (RemaKalenga). The tribal peoples in Bangladesh called it pobibaong, fao pi, faw ma (Marma); wakkhansu buphang (Tipra), napsa (Murang). U. lobata is also known as - hibiscus bur, aramina, pink Chineseburr, bur mallow, grand cousin, cadillo, carrapicho do mata, malva, mahot cousin, cousin petit, cousinrouge, jut africain, cooze mahot, dadangsi, mautofu; in Hindi: bachita, unga, lapetua; in Manipuri: sampakpi; in Marathi: vanbhendi; in Tamil: ottatti; in Telugu: nalla benda, pedda benda; in Kannada: otte (Babu et al. 2016; Medicinal Plants of Bangladesh 2017).

$U$. lobata is 0.6 to $3 \mathrm{~m}$ in height with up to $7 \mathrm{~cm}$ in basal diameter. It is an annual in subtropic and perennial in the tropics. It grows in moist regions. However, it prefers hot, humid climates, with direct sunlight and rich, well-drained soil. It is found widely in the tropical and temperate zones of North and South America and in Asia, Indonesia, the Philippines, and Africa. Moreover, it is found in cultivated crops in the Congo Basin, Central Africa, Brazil, India, and Madagascar. In Bangladesh, U. lobata is widely distributed, mainly in the lowland areas (Babu et al. 2016). The plant is also 
cultivated in many tropical countries, including South America, Africa, Australia, and the USA (Florida) (Jia et al. 2010).

The leaves of this shrub are usually broader than long, up to 11.3 $\mathrm{cm}$ in length, cordate, serrate or toothed, stellately hairy, roundish, angled; lobes generally acute or acuminate, varying in size and numbers. Flowers are small, clustered in the axils; corolla $15 \mathrm{~mm}$ long, pink. Capsules are pubescent, covered with blunt spines (Figure 1) (Medicinal Plants of Bangladesh 2017).

Box 1. Plant taxonomy
(Botanical name: Urena lobata L.)
Kingdom: Plantae
Sub-kingdom: Tracheobionta
Super-division: Spermatophyta
Division: Mangoliophyta
Class: Mangoliopsida
Sub-class: Dilleniidae
Order: Malvales
Family: Malvaceae
Genus: Urena
Species: lobata
Box 1: Plant Morphology and Habitat.

A

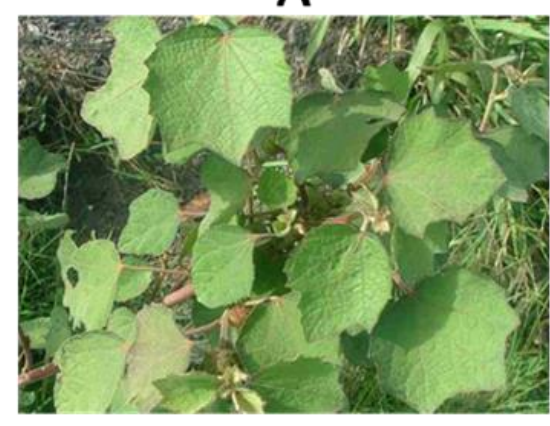

D

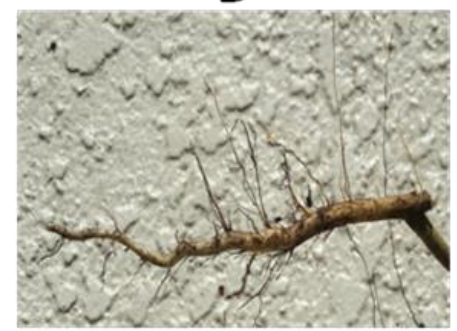

B

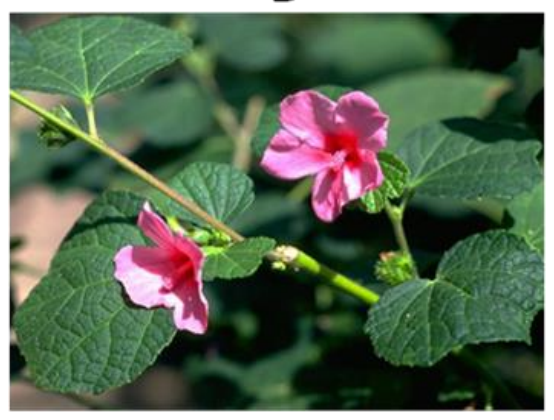

E

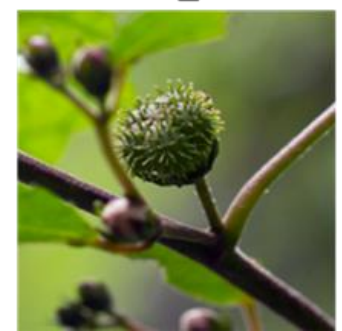

$\mathrm{F}$

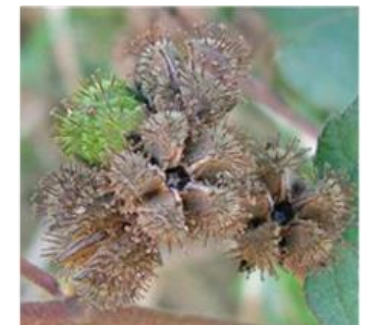

C

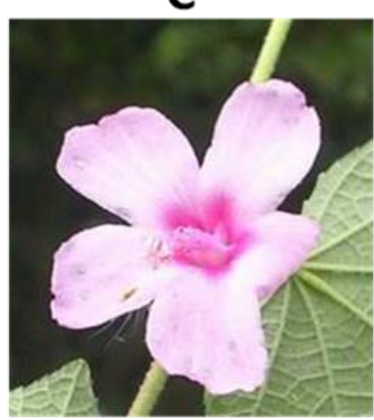

G

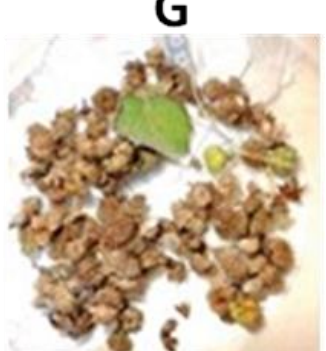

Fig. 1: Urena lobata. [A. Aerial Parts, B. Flowering Stalk, C. Flower, D. Root, E. Un-Ripe Fruit, F. Mature and Ripe Fruits, G. Seeds.]

\subsubsection{Traditional usages}

In Bangladesh, the root of $U$. lobata is used as a popular diuretic; used externally for lumbago and rheumatism, while the decoction of the stem and root is used in windy colic. The flowers are used as a pectoral and expectorant in dry coughs. Infusion of flowers is also used as a gargle for aphthae and sore-throat. Leaves are used as abscess in Rema-Kalenga (Medicinal Plants of Bangladesh 2017).

$U$. lobata has been used as a traditional medicinal plant in India and China (Gao et al. 2015). Various extracts of leaf and root are used by the traditional practitioners in herbal medicine to treat other ailments, including malaria, gonorrhea, leucorrhea, hema- temesis, carbuncle, trauma, bleeding, cold, fever, pain, numbness caused by rheumatism, wounds, toothache, and inflammation. $U$. lobata is also evident to use traditionally as an antibacterial and amoebicidal, in bronchitis, diarrhea, dysentery, edema, gastritis, cough, nephouritis, pneumonia, gingivitis, menorhagia, and emmenagogue. Moreover, it has emollient and diuretic effects (Sajem \& Gosai 2006; Jia et al. 2010).

\subsubsection{Chemical composition of $U$. lobata}

U. lobata root contains carbohydrate $33 \%$, protein $1.9 \%$, fat $1.8 \%$, fiber $51.7 \%$, moisture $6.6 \%$, and ash $5 \%$. Alkaloids, flavonoids, saponins and tannins are commonly found secondary metabolites in leaves and roots of this plant. The seeds contain the enzyme, 
urease (Medicinal Plants of Bangladesh 2017). The raw leaves are reported to contain moisture $(81.8 \%)$, protein $(3.2 \mathrm{~g})$, fat $(0.1 \mathrm{~g})$, carbohydrates (12.8 g), fiber (1.8 g), ash (2.1 g), calcium (558 $\mathrm{mg}$ ), phosphorous (67 mg), and cal (54) per $100 \mathrm{~g}$ (Babu et al 2016). To date a number of important phytochemicals have been reported in various extracts of the $U$. lobata.

Isolated compounds from $U$. lobata include: flavonoids and flavonoid glucosides from flowers, $\mathrm{C} 27-\mathrm{C} 33$ nalkanes, $\beta$-sitosterol and stigmasterol from the whole plant, imperatorin (a furocoumarin) from the root, mangiferin and quercetin from the aerial parts, unsaturated and cyclopropenoic fatty acids from the seeds, two triglycerides, namely - $\alpha$-palmitoyl- $\beta$-linoleoyl- $\alpha$-linoleoyl glycerol and $\alpha$-linoleoyl- $\beta$-linolenoyl- $\alpha^{\prime}$-oleoyl glycerol were isolated from the whole plant hexane extract of the $U$. lobata (Morelli et al. 2006).

From the aerial parts of $U$. lobata, two new compounds, such as ceplignan-4-O- $\beta$-D-glucoside and 2,5-dihydroxy benzoic acid-7(2,6-dimethyl-6-hydroxy-2,7-octadienoicacid) anhydride-5-O- $\beta$ D-apiofuranosyl $(1 \rightarrow 2)-\beta$-D-glucoside (urenoside A) as well as three new flavonoid glycosides, kaempferol-3-O- $\beta-D-$ apiofuranosyl $(1 \rightarrow 2)$ - $\beta$-Dglucopyranosyl-7-O- $\alpha$-L- rhamnopyranoside, kaempferol-4'-O- $\beta$-D-apiofuranosyl-3-O- $\beta$-Dglucopyranosyl-7-O- $\alpha$-L-rhamnopyranoside, and $5,6,7,4^{\prime}-$ tetrahydroxyflavone-6-O- $\beta$-D-arabinopyranosyl-7-O- $\alpha-\mathrm{L}-$

rhamnopyranoside were isolated, along with 5,6,7,4'tetrahydroxy-flavone-6-O- $\beta$-Dxylopyranosyl-7-O- $\alpha$-L-

rhamnopyranoside, kaempferol-7-O- $\beta$-D-glucopyranosyl $(1 \rightarrow 3)$ $\alpha$-L-rhamnopyranoside, kaempferol-3-O- $\beta$-D-glucopyranosyl-7O- $\alpha$-L-rhamnopyranoside, kaempferol-3-O- $\beta$-D-glucopyranoside, 6,8-dihydroxykaempferol-3-O- $\beta$-D-glucopyranoside, kaempferol4'-O- $\beta$-D-glucopyranoside, kaempferol-7-O- $\alpha$-Lrhamnopyranoside, kaempferol-7-O- $\alpha$-L-rhamnopyranoside-4'-O$\beta$-D-glucopyranoside, $\quad$ kaempferol-3-O-glucopyranosyl $(1 \rightarrow 3)-\beta$ D-glucopyranoside, and kaempferol-3-O-brobinobioside (Jia et al. 2010, 2011).

Two triterpenoid saponins namely (-)-trachelogenin and clematoside-S were isolated from the ethanolic leaf extract of the plant (Gao et al. 2015). Chemical structures of some isolated compounds from the parts of U. lobata have been shown in Figure 2.

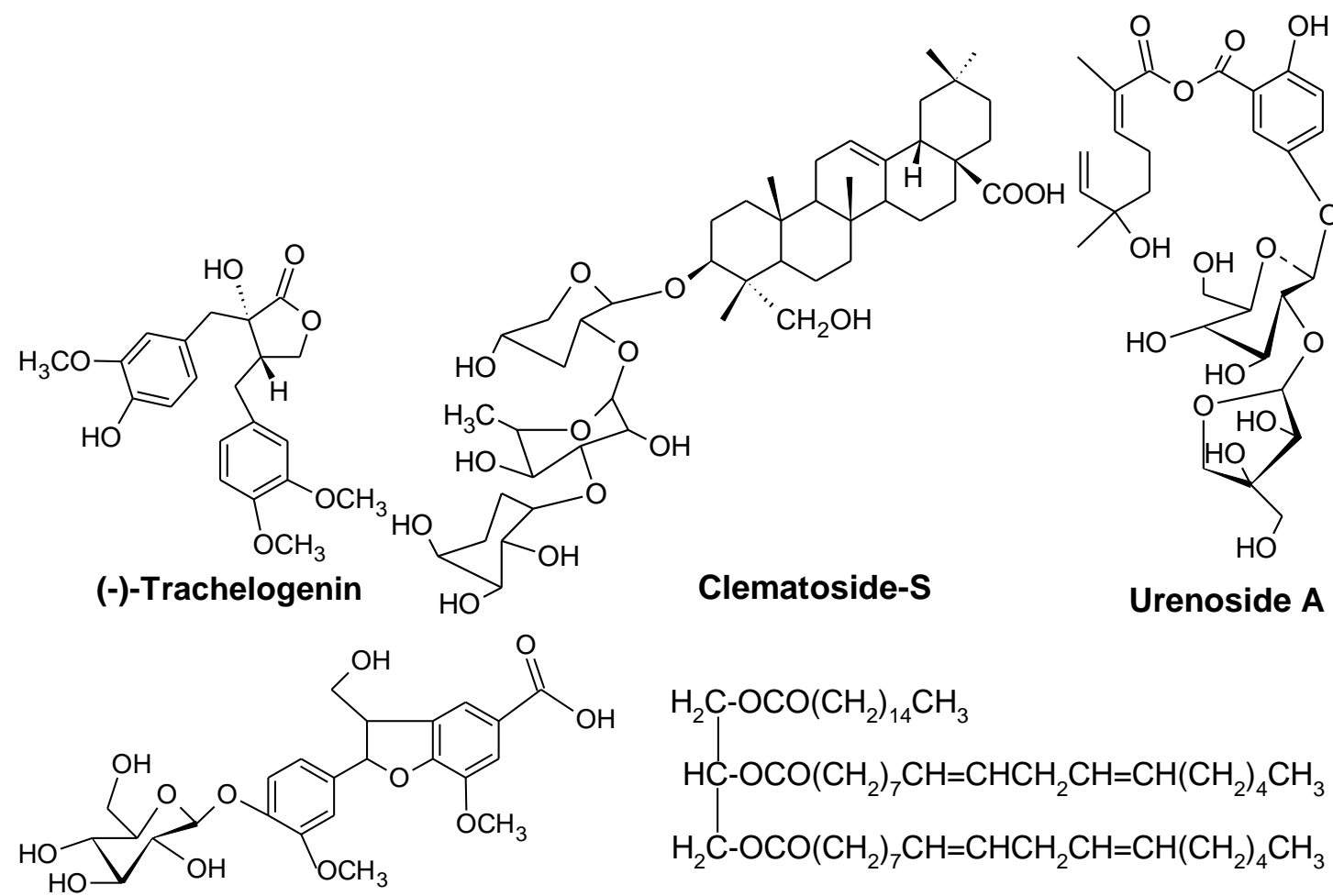

Ceplignan-4-0- $\beta$-D-glucoside

$\alpha$-palmitoyl- $\beta$-linoleoyl- $\alpha$-linoleyol glycerol

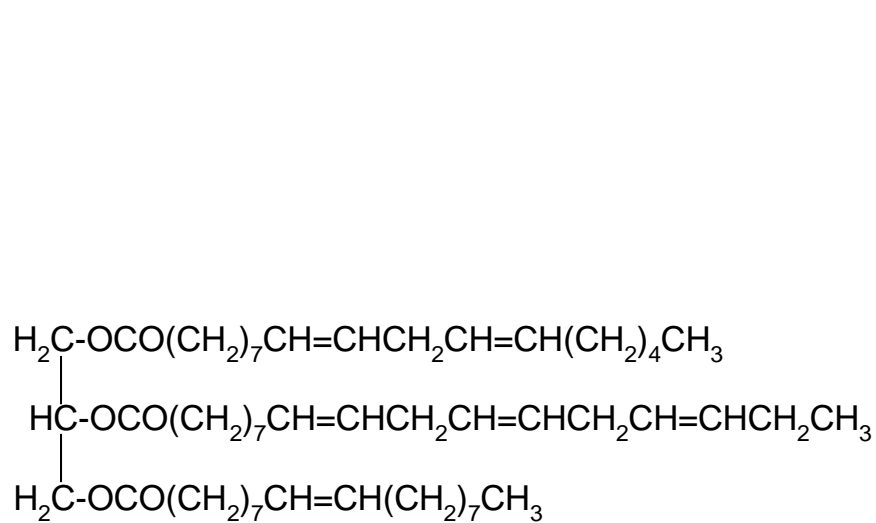

$\alpha$-linoleyl- $\beta$-linoleoyl- $\alpha^{\prime}$-oleoyl glycerol

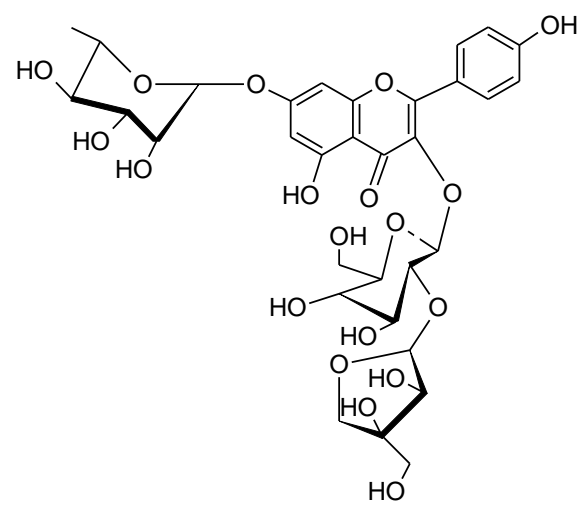

Kaempferol-3-O- $\beta$-D-apiofuranosyl $(1 \rightarrow 2)-\beta$-Dglucopyranosyl7-O- $\alpha$-L-rhamnopyranoside 


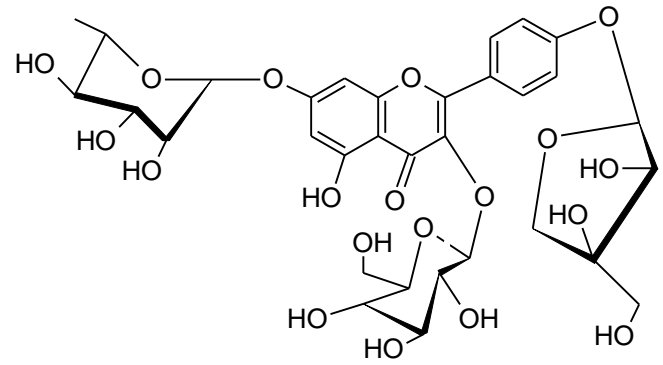

Kaempferol-4'-O- $\beta$-D-apiofuranosyl3-O- $\beta$-D-glucopyranosyl-7-O- $\alpha$-Lrhamnopyranoside<smiles>O=c1c(OC(O)C(O)C(O)C(O)C(O)C(O)O)c(-c2ccc(O)cc2)oc2cc(O)c(O)c(O)c12</smiles>

6,8-dihydroxykaempferol3-O- $\beta$-D-glucopyranoside

$\mathrm{R}=\mathrm{H}$<smiles>CC1OC2Oc3cc4oc(-c5ccc(O)cc5)cc(=O)c4c(O)c3OC3OC(O)(C(O)C3O)C(O)C2OC1O</smiles>

$5,6,7,4$ '-tetrahydroxyflavone6-O- $\beta$-D-arabinopyranosyl-7-O- $\alpha$-Lrhamnopyranoside<smiles>[R6]Oc1cc(O)c2c(=O)c(OC3OC(O)C(O)C(O)C(O)C3O)c(-c3ccc(O)cc3)oc2c1</smiles>

$\mathrm{R}=\alpha$-L-rha

(Kaempferol-3-O- $\beta$-D-glucopyranosyl-7-O- $\alpha$ L-rhamnopyranoside)

(Kaempferol-3-O-b-D-glucopyranoside)<smiles>[R20]Oc1ccc(-c2oc3cc([R20])cc(O)c3c(=O)c2O)cc1</smiles>

$R_{1}=\beta$-D-glu $(1 \rightarrow 3)$ - $\alpha$-L-rha; $R_{2}=H$

(Kaempferol-7-O- $\beta$-D-glucopyranosyl (1 $\rightarrow 3$ )- $\alpha$-L-rhamnopyranoside)

$\mathrm{R}_{1}=\mathrm{H} ; \mathrm{R}_{2}=\beta$-D-glu

(Kaempferol-4'-O- $\beta$-D-glucopyranoside)

$\mathrm{R}_{1}=\alpha$-L-rha; $\mathrm{R}_{2}=\mathrm{H}$

(Kaempferol-7-O- $\alpha$-L-rhamnopyranoside)

$R_{1}=\alpha$-L-rha; $R_{2}=\beta$-D-glu

(Kaempferol-7-O- $\alpha$-L-rhamnopyranoside-4'-O- $\beta$-D-glucopyranoside)

$\mathrm{R}_{1}=\beta$-D-glu $(1 \rightarrow 3)$ - $\beta$-D-glu; $\mathrm{R}_{2}=\mathrm{H}$

(Kaempferol-3-O-glucopyranosyl (1 $\rightarrow-3)$ - $\beta$-D-glucopyranoside)

$\mathrm{R}_{1}=$ robinobioside; $\mathrm{R}_{2}=\mathrm{H}$

(Kaempferol-3-O- $\beta$-robinobioside)

Fig. 2: Chemical Structures of some Important Phytochemicals Isolated from U. lobata.

Biological and other activities of $U$. lobata

\subsubsection{Antioxidant capacity}

Methanolic root extract of $U$. lobata was found to inhibit lipid peroxidation, scavenge hydroxyl $\left({ }^{\bullet} \mathrm{OH}\right)$ and superoxide radicals $\left(\mathrm{O}_{2}{ }^{\bullet-}\right)$ in vitro. The half-minimal inhibitory concentrations $\left(\mathrm{IC}_{50 \mathrm{~s}}\right)$ of root extract of $U$. lobata were 470.60, 1627.35 and 1109.24 $\mu \mathrm{g} / \mathrm{mL}$ for $\mathrm{O}_{2}{ }^{\bullet-}$ and ${ }^{\bullet} \mathrm{OH}$ scavenging and lipid peroxidation, respectively (Lissy et al. 2006). In another study, the U. lobata extract was found to reduce pancreatic malondialdehyde (MDA), lipid peroxidation and oxidative stress in the rabbit liver (Omonkhua \& Onoagbe 2008).

\subsubsection{Anti-inflammatory/membrane stabilization activity}

The ethanol leaf extract of $U$. lobata at 250 and $500 \mathrm{mg} / \mathrm{kg}$ (p.o.) is evident to exert an anti-inflammatory effect in Swiss albino mice and male Sprague-Dawley rats (Babu et al. 2016). Moreover, the ethanol extract of the aerial parts was also reported for significant anti-inflammatory and membrane stabilization capacity in egg-albumin and human red blood cell (HRBC), respectively (Islam et al. 2012).

\subsubsection{Wound healing effect}

The methanolic extract of the plant in comparison to the povidone-iodine formulation in albino rats was found to show a significant wound healing capacity in excision, incision, burn, and dead space wound models (Mathappan et al. 2013).

\subsubsection{Anti-diarrheal/anti-motility activity}

The seed extract of $U$. lobata was found to reduce castor oil-induced diarrhea and prostaglandin E2 (PGE2)-induced intrafluid accumulation in rodents (Yadav \& Tangpu 2007). The etha- 
nol extract of the aerial parts of $U$. lobata at 250 and $500 \mathrm{mg} / \mathrm{kg}$ was also evident to a significant anti-motility activity in charcoalmeal defecation mice (Islam et al. 2012).

\subsubsection{Antimicrobial activity}

Methanol root extract of $U$. lobata $(125-1000 \mu \mathrm{g} / \mathrm{mL})$ was found to act against a number of Gram (+) and Gram (-) bacteria, including Bacillus subtilis, Staphylococcus aureus, Staphylococcus epidermidis, Micrococcus luteus, Escherichia coli, Klebsiella pneumonia, Shigella dysenteriae and Vibrio cholerae, where the zones of inhibition were observed between 8 and $21 \mathrm{~mm}$ (Mazumder et al. 2001). The isolated compounds from the leaf extract of the plant such as kaempferol, quercetin, and tiliroside were found to act against $B$. subtilis, E. coli and $K$. pneumonia (Adewale et al. 2007). On the other hand, the ethanol $(80 \%)$ extract of the plant revealed a significant anti-fungal activity against Aspergillus niger (strain: ATCC 16404) Saccharomyces cerevisiae (strains: AY529515.1, AJ746340.1, JX103178.1, KG254081.1 and ATCC 204508), where zones of inhibition were observed between 9 and $20 \mathrm{~mm}$ for the crude extract and isolated compound, clematosideS (Gao et al. 2015). In the latter case, the minimum inhibitory concentration (MIC) values against $S$. cerevisiae strains were detected within the range of 0.61 and $9.8 \mu \mathrm{g} / \mathrm{mL}$.

\subsubsection{Cytotoxic and anticancer activities}

The methanol leaf extract of the plant is evident to show a significant cytotoxic effect in Artemia salina (Ali et al. 2013) as well as anti-proliferative and antioxidant effect on breast cancer cell (MB-MDA435) line (Pieme et al. 2012).

\subsubsection{Effects on reproductive system}

The ethanolic $(70 \% \mathrm{v} / \mathrm{v})$ root extract or $U$. lobata (300 and 600 $\mathrm{mg} / \mathrm{kg}$ once daily for 55 days, p.o.) in adult male Wistar albino rats, reversibly inhibited spermatogenesis and steroidogenesis, indicating reversible anti-fertility activity without decreasing the body weight. However, the weight of testes, epididymides and seminal vesicles were significantly $(p<0.01)$ reduced. A significant $(\mathrm{p}<0.01)$ reduction in the sperm motility, viability and counts, epididymal and testicular protein contents were also observed at $600 \mathrm{mg} / \mathrm{kg}$ dose along with a marked increase in sperm morphological abnormalities, testicular cholesterol and ascorbic acid contents. Furthermore, the activities of testicular glucose-6-

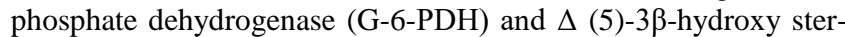
oid dehydrogenase $(\Delta(5)-3 \beta-H S D)$ were found to reduce significantly. However, these changes were reversed after the treatment period (after 55 days) (Dhanapal et al. 2012).

\subsubsection{Anti-diabetic/ hypolipidemic activity}

Ethanolic and hot aqueous leaf extracts of $U$. lobata exhibited dipeptidyl peptidase IV (DPP-IV) inhibitory activity within the IC 50 values of 1654.64 and $6489.88 \mu \mathrm{g} / \mathrm{mL}$, respectively, suggesting a significant anti-diabetic activity. The responsible compounds were thought to be mangiferin, stigmasterol and $\beta$ sitosterol (Purnomo et al. 2015). On the other hand, the methanolic leaf extract is reported for anti-hyperglycemic activity (Islam et al. 2015). In a recent study, oral administration of aqueous leaf extract of $U$. lobata at doses of 250,500 , and $1000 \mathrm{mg} / \mathrm{kg}$ in male Sprague-Dawley rats $(n=5)$; prevented degradation of glucagonlike peptide-1 (GLP-1) by inhibition of DPP-4 activity, suggesting an improvement in the structure and function of islet $\beta$-cells by increasing of GLP-1 bioavailability (Purnomo et al. 2016). Moreover, in a previous study, Onoagbe et al (2010) suggested that, the aqueous extracts of the $U$. lobata (roots and leaves) have antidiabetic/hypoglycemic effects in streptozotocin (STZ) -induced diabetic rats.

\subsubsection{Neuropharmacological activity}

The ethanol extract ( 250 and $500 \mathrm{mg} / \mathrm{kg}$, p.o.) of the aerial parts of $U$. lobata is evident to exert a significant analgesic effect in acetic acid-induced writhing test in Swiss mice (Islam et al. 2012). In another study, Islam et al (2014) reported that, the hexane, ethyl acetate, chloroform, acetone and methanol fractions of the $U$. lobata exerted a sedative-like effect at $400 \mathrm{mg} / \mathrm{kg}$ (p.o.) in Swiss mice. Islam et al (2015) suggested that, the methanolic leaf extract of the $U$. lobata exerted an anti-nociceptive effect in Swiss mice. In a recent study, ethanol leaf extract $(250$ and $500 \mathrm{mg} / \mathrm{kg}$, p.o.) of $U$. lobata was found to exert significant anxiolytic, anti-depressant and anti-inflammatory effects in Swiss albino mice and male Sprague-Dawley rats (Babu et al. 2016).

\subsubsection{U. lobata in analytic chemistry}

Eze and Ogbuefi (2014) reported that, the flower extract of the $U$. lobata can be used as an acid-base indicator in titration, due to the efficiency, availability, inertness, ease of preparation, and economy.

\subsubsection{Toxicological reports}

Oladele and Abatan (2010) in a pilot toxicity study in albino rats suggested that, the $U$. lobata exerted a significant increase in headless tail sperm cell abnormality in male albino rats. In another study, the aqueous root extract of the plant showed some biochemical and histopathological alterations in the liver of adult Wistar rats (Mshelia et al. 2013). However, in an acute study, ethanol leaf of $U$. lobata up to $2000 \mathrm{mg} / \mathrm{kg}$ (p.o.) showed neither abnormal clinical signs nor mortality in Swiss albino mice and male Sprague-Dawley rats (Babu et al. 2016).

\section{Conclusion}

The review suggests that, the $U$. lobata contains a number of important phytochemicals. A few of them are already evident to have promising biological activities. The hydro-/alcoholic or other organic crude extract of leaves, aerial parts and roots are the frequently evaluated for biological activities in in vitro, ex vivo and in vivo test systems. The plant has various biological activities, despite of inadequate scientific evidence in each activity. Therefore, more research is necessary for this hopeful medicinal plant.

\section{Conflict of interest}

None declared.

\section{References}

[1] Adewale AO, David AA, Abiodun OO. 2007. Studies on antimicrobial, antioxidant and phytochemical analysis of Urena lobata leave extract. J. Phys. Nat. Sci. 1:12-20.

[2] Ali S, Faruq KO, Rahman AA, Hossain MA. 2013. Antioxidant and cytotoxic ativities of methanol extract of Urena lobata (L.) Leaves. Pharm. Innov. J. 2:9-14.

[3] Babu SS, Madhuri DB, Ali SL. 2016. A pharmacological review of Urena lobata plant. Asian J. Pharm. Clin. Res. 9:20-22.

[4] Babu SS, Madhuri DB, Reddy DS. 2016. Anxiolytic antidepressant and anti-inflammatory activity of ethanolic extract of Urena lobata leaf. Int. J. Pharm. Res. Health Sci. 4:1284-1290. https://doi.org/10.21276/ijprhs.2016.04.07.

[5] Dhanapal R, Ratna JV, Gupta M, Sarathchandran I. 2012. Preliminary study on antifertility activity of Enicostemma axillare leaves and Urena lobata root used in Indian traditional folk medicine. Asian Pac. J. Trop. Med. 5:616-622. https://doi.org/10.1016/S19957645(12)60127-8.

[6] Eze SO, Ogbuefi RA. 2014. Analytical potentials of dye extracts from Urena lobata (Mgbo) flowers. Commun. Appl. Sci. 2:25-35.

[7] Gao XL, Liao Y, Wang J, Liu XY, Zhong K, Huang YN, Gao H, Gao B, Xu ZJ. 2015. Discovery of a potent anti-yeast triterpenoid 
saponin, clematoside-S from Urena lobata L. Int. J. Mol. Sci. 16:4731-4743. https://doi.org/10.3390/ijms16034731.

[8] Islam H, Hasanur Rahman KM, Rahman S, Rahmatullah M. 2015. Preliminary antihyperglycemic, antinociceptive activity, phytochemical analysis and toxicity studies on leaves of Urena lobata $\mathrm{L}$. J. Chem. Pharm. Res. 7:559-563.

[9] Islam MT, Freitas RM, Oliveira GLS, Guha B. 2014. Neuropharmacological screenings of hydroalcoholic fractions of Urena lobata L. World J. Pharm. Pharmaceut. Sci. 3:62-71.

[10] Islam MT, Ibrahim M, Ahsan MQ, Chowdhury MMU, Hossain MA, Rashid MA. 2012. Phytochemical and Pharmacological Investigations of Uraria lagopodies DC. and Urena lobata L. Dhaka Univ. J. Pharm. Sci. 11:65-69. https://doi.org/10.3329/dujps.v11i1.12490.

[11] Islam MT, Mata AMOF, Aguiar RPS, Paz MFCJ, de Alencar MVOB, de Melo-Cavalcante AAC. 2016. Therapeutic Potential of Essential Oils Focusing on Diterpens. Phytother. Res. 30:14201444. https://doi.org/10.1002/ptr.5652.

[12] Jia L, A YM, Jing LL, Zhou SA, Kong DY. 2011. Three new flavonoid glycosides from Urena lobata. J. Asian Nat. Prod. Res. 13:907-914. https://doi.org/10.1080/10286020.2011.599802.

[13] Jia L, Bi YF, Jing LL, Zhou SA, Kong DY. 2010. Two new compounds from Urena lobata L. J. Asian Nat. Prod. Res. 12:962-967. https://doi.org/10.1080/10286020.2010.510468.

[14] Lissy KP, Simon TK, Lathab MS. 2006. Antioxidant potential of Sida retusa, Urena lobata and Triumfetta rhomboidea. Anc. Sci. Life 25:10-15.

[15] Mathappan R, Umachigi SP, Prasanth VV. 2013. Wound healing activity of the methanolic extract of Urena lobata Linn. Int. J. Pharm. Chem. Sci. 2:793-800.

[16] Mazumder UK, Gupta M, Manikandan L, Bhattacharya S. 2001. Antibacterial activity of Urena lobata root. Fitoterapia 72:927-929. https://doi.org/10.1016/S0367-326X(01)00330-6.

[17] Medicinal Plants of Bangladesh (MPB). 2017. Link: http://www.mpbd.info/plants/urena-lobata.php.

[18] Morelli CF, Cairoli P, Speranza G, Alamgir M, Rajia S. 2006. Triglycerides from Urena lobata. Fitoterapia 77:296-299. https://doi.org/10.1016/j.fitote.2006.03.010.

[19] Mshelia IY, Dalori BM, Hamman LL, Garba SH. 2013. Effect of the aqueous root extract of Urena lobata (Linn) on the liver of albino rat. Res. J. Appl. Sci. Eng. Technol. 5:1-6.

[20] Oladele GM, Abatan MO. 2010. Haematological and sperm coun changes following exposure to Hyptis suaveolens, Cleome viscosa and Urena lobata in rats. Nig. Vet. J. 31:170-176.

[21] Omonkhua AA, Onoagbe IO. 2008. Effects of Irvingia grandifolia, Urena lobata and Carica papaya on the oxidative status of normal rabbits. Internet J. Nutr. Wellness 6:1-11.

[22] Onoagbe IO, Negbenebor EO, Ogbeide VO, Dawha IH, Attah V, Lau HU, et al. 2010. A study of the anti-diabetic effects of Urena lobata and Sphenostylis stenocarpa in streptozotocin-induced diabetic rats. Eur. J. Sci. Res. 43:6-14.

[23] Pieme CA, Ngogang J, Costache M. 2012. In vitro antiproliferative and anti-oxidant activities of methanol extracts of Urena lobata and Viscum album against breast cancer cell lines. Toxicol. Environ. Chem. 94:1-13. https://doi.org/10.1080/02772248.2012.674135.

[24] Sajem AL, Gosai K. 2006. Traditional use of medicinal plants by the Jaintia tribes in North Cachar Hills district of Assam, northeast India. J. Ethnobiol. Ethnomed. 2:1-7. https://doi.org/10.1186/17464269-2-1.

[25] Purnomo Y, Soeatmadji DW, Sumitro SB, Widodo MA. 2016. Incretin effect of Urena lobata leaves extract on structure and function of rats islet $\beta$-cells. J. Trad. Compl. Med. https://doi.org/10.1016/j.jtcme.2016.10.001.

[26] Purnomo Y, Soeatmadji DW, Sumitro SB, Widodo MA. 2014 Po145 the comparison of activity dipeptidyl peptidase IV (DPP-IV) inhibitor between Urena lobata and Tithonia diversifolia leaf extract. Diabet. Res. Clin. Pract. 106:S121. https://doi.org/10.1016/j.jtcme.2016.10.001.

[27] Yadav AK, Tangpu V. 2007. Antidiarrheal activity of Lithocarpus dealbata and Urena lobata extracts: Therapeutic implications. Pharm. Biol. 45:223-229. https://doi.org/10.1080/13880200701213153.

[28] Purnomo Y, Soeatmadji DW, Sumitro SB, Widodo MA. 2015. Anti-diabetic potential of Urena lobata leaf extract through inhibition of dipeptidyl peptidase IV activity. Asian Pac. J. Trop. Biomed. 5:645-649. https://doi.org/10.1016/j.apjtb.2015.05.014. 